\title{
KEKUASAAN GURU DALAM BIROKRASI PEMERINTAHAN DAERAH
}

\author{
Arif Rohman \\ Universitas Negeri Yogyakarta \\ email: arv_2013@yahoo.co.id
}

\begin{abstract}
Abstrak: Kekuasaan Guru dalam Birokrasi Pemerintahan Daerah. Penelitian ini bertujuan untuk mengungkap tiga hal, yaitu: (1) konsep pemahaman guru tentang kekuasaan; (2) motif guru dalam memilih menjadi pejabat di jajaran birokrasi pemerintah; (3) cara guru dalam meraih kekuasaan birokrasi. Penelitian dilakukan dengan pendekatan kualitatif model fenomenologis di wilayah kabupaten Bantul. Hasil penelitian ini adalah: (1) guru memahami kekuasaan sebagai amanah dan peluang untuk terlibat dalam pembangunan pendidikan. Apabila amanah datang maka wajib bagi guru untuk menerima dan menjalankannya. (2) motif guru memilih menjadi pejabat di birokrasi pemerintah adalah agar menjadi pelaku langsung dalam pembangunan pendidikan. Menjadi pejabat bagi guru adalah penting dari pada jabatan tersebut dipegang oleh orang yang tidak mengetahui pendidikan. Apabila jabatan dipegang oleh orang yang tidak memahami pendidikan akan berakibat fatal. (3) Cara guru dalam meraih kekuasaan birokrasi adalah melalui PGRI. Penguasa sangat berkepentingan terhadap PGRI dalam rangka menguasai guru, begitu juga guru melalui PGRI dapat lebih dekat dengan penguasa.
\end{abstract}

Kata kunci: Kekuasaan birokrasi, motif guru, dan kemajuan pendidikan.

\begin{abstract}
The Powers of Teachers in The Local Government Bureaucracy. This research was aimed to reveal three things, namely: (1) teachers' understanding of the concept of power, (2) the motives of teachers in choosing to become an official in the government bureaucracy, (3) how the teacher came to power in the bureaucracy. The study was conducted with a qualitative approach with phenomenological models in Bantul district. The results of this study were: (1) teachers' understanding of power as a mandate and an opportunity to be involved in the development of education. When the mandate came, then it is obligatory for teachers to accept and run it. (2) the motives of teachers to choose to become officials in the government bureaucracy is to be direct actors in the development of education. Being officials, it is important for teachers than if the position held by people who do not know the education. if the department is held by people who do not understand education, it will be fatal. (3) How teachers in eliciting power of bureaucracy is by PGRI. Authorities is very interested in the PGRI in order to dominate teachers, as well as teachers by PGRI can be closer to authorities.
\end{abstract}

Key words: The power of the bureaucracy, the motives of the teachers, and educational advancement.

\section{PENDAHULUAN}

Guru merupakan sosok yang memiliki kedudukan sentral dalam proses pembelajaran. Guru menjadi orang yang paling menentukan dalam perancangan dan penyiapan proses pembelajaran di sekolah. Umar Tirtarahardja dan La Sulo (1994) menyebut kedudukan guru di sekolah amat kompleks, sebagai manager, direktur, organisator, koordinator, komunikator, fasilitator, dan stimulator. Kedudukan guru yang demikian penting, menjadikannya berperan amat strategis dalam kancah penentuan keberhasilan pendidikan dan pembelajaran. Dalam skala lebih luas, guru berperan penting dalam keberhasilan pembangunan di masyarakat. 
Secara historis, guru dalam tradisi Jawa kuno dianggap sebagai manusia mulia menjadi tempat bertanya, pembimbing spiritual, dan teladan bagi masyarakat. Tradisi spiritual sufi, menempatkan guru sebagai sosok dengan sifat kamil mukammila. Tradisi Hindu India, guru dikenal sebagai 'maha resi guru' yakni orang yang tugasnya mendidik calon biksu di Bhinaya Panti, tempat pendidikan para biksu, yang mengajak muridnya untuk mencapai kelepasan dari kesengsaraan (samsara), (Zen Rachmat Sugito dkk, 2006).

Sebagai sosok pribadi yang terpuji, kedudukan dan peran guru tidaklah kecil di mata masyarakat. Frederick Meyer (Dirto Hadisusanto dkk, 1995) mensinyalir guru mempunyai kedudukan penting sebagai sumber keteladanan dan berperan dalam menjaga peradaban sekaligus pelindung kemajuan masyarakat. Oleh karenanya, guru merupakan sosok penting "as a process leading to the enlightenment of mankind".

Keterlibatan guru bersama masyarakat merupakan cerminan relasi antar keduanya beserta dinamika yang terjadi seiring dengan intensitas relasi yang dibangun. Keterlibatan guru bersama masyarakat menjadikannya relatif memahami aneka persoalan kemasyarakatan. Akibatnya, guru sering terlibat secara kolaboratif dan supportif dalam interaksi dengan aneka kelompok kepentingan masyarakat (societal interest group).

Joel Spring (1993) menyebutkan dalam proses interaksi kemasyarakatan tersebut, guru menjadi bagian penting di dalamnya. Secara politis, ada tujuh kelompok kepentingan yang terlibat dalam interaksi masyarakat terkait pendidikan, yaitu: (1) politicians of political party, (2) education politicians, (3) boards of education, (4) courts, (5) foundations, (6) corporate sector, dan (7) teachers' unions. Tujuh kelompok kepentingan tersebut saling berinteraksi dalam relasi kekuasaan terkait penyelenggaraan pendidikan (Joel Spring, 1993). Lebih jauh dalam relasi kekuasaan tersebut terjadi bargaining of interest, baik yang bersifat hard bargaining atau pun sebaliknya (Joetta
L. Sack (2002).

Hasil penelitian dari Kenneth K. Wong (2006), J. Wagman (2003), J. Rubin and R. Fausset (2005) menyebutkan bahwa banyak kasus pemilihan walikota di Amerika Serikat, issu-issu pendidikan menjadi bagian penting dalam materi kampanye para kandidat. Kenneth K. Wong (2006) menyebutkan, "Five of the six candidates said they wouldn't hesitate to push for a takeover if the city's schools were to lose their accreditation". Secara umum, issu pendidikan dalam pemilu di AS meliputi: penguatan kepemimpinan dalam pendidikan publik, reformasi sekolah, dan peningkatan mutu sekolah. Hal ini tidak berbeda dengan yang ada di Indonesia, banyak ahli menyebutkan bahwa setiap kali musim pemilu, isu-isu perbaikan pendidikan selalu menjadi bagian penting dalam kampanye.

Secara teoritis, kekuasaan (authority) diartikan amat beragam oleh para ahli. Lasswell dan Kaplan (Cheppy, 1991) mengartikan kekuasaan sebagai 'the participation in the making of decisions'. Roger H. Soltau (Cheppy, 1991) melihat kekuasaan sebagai 'the capacity to make one's will prevail over that of other's, even against these other wills'. Meriam Budiharjo (Cheppy, 1991) menyebutkan kekuasaan sebagai kemampuan seseorang untuk mempengaruhi tingkah laku orang lain sedemikian rupa sehingga orang lain tersebut mengikuti sesuai dengan keinginan orang yang mempunyai kekuasaan itu.

Ada dua macam jenis kekuasaan (authority/power), yaitu transmitive power dan transformative power (HAR Tilaar, 2003). Kekuasaan jenis pertama adalah suatu kekuasaan yang bertujuan membentuk hubungan subordinasi antar subyek dengan subyek lain, sehingga memunculkan adanya kepatuhan dan kesetiaan. Sedangkan kekuasaan jenis kedua adalah suatu kekuasaan yang bertujuan tidak untuk membentuk hubungan subordinasi, melainkan membangkitkan refleksi pihak lain sehingga menimbulkan aksi kritis. Jenis pertama lebih berorientasi legitimatif, sedangkan jenis kedua lebih berorientasi advokatif. 
Kekuasaan dalam pendidikan dapat dibedakan menjadi dua, yaitu: kekuasaan makro dan mikro. Kekuasaan makro kekuasaan makro mencakup kekuasaan dalam penyiapan, perumusan, penetapan, dan implementasi kebijakan pendidikan di lembaga pemerintahan baik tingkat nasional, provinsial, maupun distrikal yaitu kabupaten/kota. Adapun kekuasaan mikro mengarah pada kekuasaan dalam pengelolaan sekolah dan kelas meliputi: (1) menyusun visi, misi, dan sasaran; (2) menyusun rencana strategis dan program kegiatan baik jangka pendek, menengah, maupun panjang; (3) menyusun kurikulum sekolah sesuai kreasi dan otonomi sekolah; (4) menyiapkan silabus mata pelajaran sekolah; (5) Menyiapkan Rencana Pelaksanaan Pembelajaran (RPP) untuk setiap kali akan diselenggarakan tatap muka pembelajaran; (6) melakukan proses pembelajaran di dalam kelas dengan memakai alat dan perangkat yang dikehendaki; (7) Memilih media pembelajaran yang dianggapnya relevan untuk pembelajaran; (8) Melakukan evaluasi dan penilaian kepada siswa untuk mengetahui hasil pembelajaran.

Dalam penelitian ini penekanan kekuasaan guru lebih difokuskan pada kekuasaan makro dalam pendidikan, yaitu pemahaman para guru yang telah beralih tugas menjadi pejabat di jajaran birokrasi pemerintahan daerah dalam memahami kekuasaan, motifmotif yang dimiliki, dan cara guru meraih kekuasaan di dalam jajaran birokrasi pemerintahan. Kekuasaan untuk mengatur dan memerintah, membutuhkan cara-cara yang tepat dalam menjalankan serta memerlukan sumber dari asal usul kekuasaan. Mengenai pelaksanaan dan sumber kekuasaan, para ahli menganalisisnya ke dalam empat faktor. Keempat faktor itu meliputi: (1) bentuk dan jumlah sumber kekuasaan, (2) distribusi sumber kekuasaan, (3) waktu penggunaan sumber kekuasaan, dan (4) hasil penggunaan sumber kekuasaan.

Ramlan Surbakti (1992) menyebutkan yang termasuk kategori sumber kekuasaan ialah sarana paksaan fisik, kekayaan dan harta benda, normatif, jabatan keahlian, informasi, status sosial, popularitas pribadi, dan massa yang terorganisasi. Adapun cara untuk memudahkan pelaksanaan kekuasaan melalui apa yang disebut Teknologi Kontrol Politik (TKP), antara lain dengan lembaga intelijen negara untuk mendeteksi gerak-gerik kelompok militan. Ada juga alat teknologi canggih sebagai pengendalian huru hara, metode psikologi dan aneka teknik interogasi, dan penggunaan penyiksaan sebagai alat intimidasi.

Selain bentuk dan sumber kekuasaan, distribusi sumber kekuasaan juga merupakan hal penting. Sumber kekuasaan tidak terdistribusikan secara merata dalam setiap masyarakat, karena kemampuan setiap orang amat bervariasi. Ketidakmampuan seseorang mungkin karena diciptakan oleh orang lain, oleh karenanya ia mudah dikuasai dan selalu menjadi pengikut kepada orang yang menciptakannya. Akan tetapi ketidakmampuan seseorang mungkin juga terjadi karena yang bersangkutan tidak lagi bersemangat untuk mengubah nasib dirinya. Dengan kata lain ia sudah pasrah dengan keadaan yang ada.

Seiring dengan adanya otonomi daerah sejak dikeluarkannya Undang-Undang (UU) No. 22 tahun 1999 tentang pemerintahan daerah, yang telah direvisi menjadi UU No. 32 tahun 2004 dan disempurnakan dengan UU No. 12 tahun 2008, telah terjadi perubahan prinsip dan arah baru dalam pengelolaan pemerintahan, termasuk di dalamnya adalah sektor pendidikan. Otonomi daerah adalah hak, wewenang, dan kewajiban daerah otonom untuk mengatur dan mengurus sendiri urusan pemerintahan dan kepentingan masyarakat setempat sesuai dengan peraturan perundang-undangan.

Melalui otonomi daerah diharapkan dapat terjadi arah baru perjalanan pendidikan nasional yang panjang menuju pencapaian yang lebih baik. Otonomisasi pendidikan melalui berbagai instrumen kebijakan telah dilakukan, mulai dengan disusunnya Undang-Undang RI Nomor 20 tahun 2003 tentang Sistem Pendidikan Nasional, "pri- 
vatisasi" pendidikan melalui pengesahan Undang-Undang RI nomor 9 tahun 2009 tentang Badan Hukum Pendidikan meskipun sekarang telah diamulir oleh Mahkamah Konstitusi, diharapkan dapat memajukan dunia pendidikan, yang mampu melahirkan insan-insan akademis dan intelektual yang diharapkan dapat membangun bangsa secara demokratis.

Namun banyak kasus, guru sering hanya dijadikan sebagai alat kepentingan oleh penguasa di daerah. Aneka praktek ketidakadilan penguasa daerah terhadap guru sebagaimana dilaporkan Republika, "Saat pelaksanaan pilkada, banyak kepala daerah main ancam kepada guru akan dimutasi ke daerah terpencil atau diturunkan statusnya dari kepala sekolah menjadi guru bantu" (Republika, 22 Nopember 2011). Menurut Laksana (2011), praktek kekuasaan despotik yang diperagakan penguasa daerah terhadap guru tersebut dilakukan melalui bentuk-bentuk mutation (pergeseran) dan demotion (penurunan).

Relasi kekuasaan antar berbagai kelompok kepentingan di atas, dapat memberikan peluang sekaligus tantangan bagi guru dalam menempatkan dirinya secara kritis. Relasi kekuasaan bisa dimaknai berbeda oleh guru dibandingkan oleh kelompok lain, sehingga penelitian ini lebih difokuskan untuk mengungkap fakta-fakta tentang kekuasaan dan mendeskripsikannya menurut makna yang dipahami guru. Oleh karenanya, rumusan masalah dalam penelitian ini adalah "bagaimanakah makna kekuasaan bagi guru?" yang kemudian dijabarkan menjadi beberapa pertanyaan operasional, yaitu: (1) bagaimana pemahaman guru tentang kekuasaan?, (2) apa motif guru dalam memilih menjadi pejabat di jajaran birokrasi pemerintah?, (3) cara apa yang dilakukan guru untuk meraih kekuasaan birokrasi pemerintahan?

\section{METODE}

Pendekatan dalam penelitian ini adalah kualitatif model fenomenologis. Pendekatan ini dipilih disebabkan masalah yang diteliti merupakan fenomena dinamikkompleks. Melalui pendekatan ini peneliti dapat mengungkap makna yang lebih mendalam tentang fakta yang diteliti. Pendekatan ini dilakukan dengan melihat bahwa masyarakat merupakan realitas subyektif sekaligus obyektif. Sebagai realitas subjektif, masyarakat telah menghasilkan individu melalui proses yang disebut reifikasi. Melalui sosialisasi, individu menyatukan dua hal yaitu primary socialization dan secondary socialization untuk berpartisipasi dalam struktur kelembagaan sosial dalam realitas objektif.

Setting penelitian yang dipilih adalah wilayah Bantul, karena beberapa alasan: Pertama, Bantul merupakan bagian penting dari DIY, dimana DIY dikenal sebagai propinsi dengan indeks pendidikan di atas rata-rata nasional serta memiliki status pemerintahan istimewa (UU No. 3 Tahun 1950 tentang Pembentukan Daerah Istimewa Yogyakarta). Kedua, Bantul memiliki struktur kekuasaan birokrasi pendidikan yang berbeda dengan kabupaten/kota lain di DIY dan Jawa Tengah. Bantul memiliki dua dinas pendidikan dalam sistem pemerintahan daerah, yaitu dinas pendidikan dasar dan dinas pendidikan menengah dan nonformal. Ketiga, wilayah Bantul adalah wilayah yang paling modiokratis diantara keseluruhan wilayah lain di DIY dalam banyak segi ekonomi, sosial, dan budaya. Keempat, Dari segi budaya politik, daerah ini memiliki tradisi dimana kraton Ngayogyakarta Hadiningrat merupakan simbol dan sumber legitimasi kekuasaan.

Subjek penelitian dipilih secara purposive yang meliputi unsur dari pejabat Dinas Pendidkan, kepala sekolah, dan guru. Pejabat dinas adalah sosok kepala dinas pendidikan dasar yang sebelumnya adalah seorang guru. Kepala sekolah dipilih 3 orang yaitu dari satuan pendidikan SD, SMP, dan SMA. Subyek dari unsur guru dipilih 6 orang guru yaitu 2 orang guru SD, 2 orang guru SMP, dan 2 orang guru SMA. Total subyek penelitian terpilih sebanyak 10 orang subyek penelitian yang dipilih secara purposive. 
Pencarian data dilakukan melalui wawancara mendalam. Pencarian data melalui wawancara mendalam ini dilakukan kepada subyek penelitian terpilih untuk menggali data-data verbal serta untuk mencari kedalaman makna atas temuan yang ada. Adapun dalam rangka mencari aseptabilitas data dan kredibilitas sumber data dilakukan trianggulasi. Adapun trianggulasi yang dipilih meliputi tiga jenis, yaitu: Pertama, trianggulasi dengan menyepakatkan data dengan sumber datanya. Kedua, trianggulasi dengan diskusi ahli terutama dengan teman-teman di Universitas Negeri Yogyakarta. Ketiga, trianggulasi melalui mencocokkan data dengan teori (rival explanations).

Data-data yang terkumpul kemudian ditrianggulasi, selanjutnya dianalisis oleh peneliti sesuai dengan pola analisis kualitatif fenomenologis sebagaimana yang diusulkan oleh John W. Creswell (2007). Adapun proses analisis kualitatif fenomenologis yang dimaksud dilakukan dengan langkah-langkah analisis data sebagaimana disarankan John W. Ceeswell melalui enam proses, yaitu: data managing, reading and memoing, describing, classifying, interpreting, dan visualizing.

Awal mula dalam analisis data adalah dengan data managing. Langkah ini dilakukan dengan menyusun dan mengorganisasi file data yang telah terkumpul. Selanjutnya dilakukan reading and memoing dengan cara membaca teks hasil wawancara. Pembacaan teks tersebut dilakukan secara cermat, dengan memberikan atau membuat catatan pinggir sebagai kunci-kunci penting. Langkah berikutnya adalah describing, yang dilakukan dengan mendeskripsikan pengalaman personal dari para subjek dan mendeskripsikan esensi dari suatu fenomena yang diteliti. Langkah keempat adalah classifying, wujud langkah ini adalah peneliti mengembangkan aneka pernyataan signifikan dan mengelompokkan aneka pernyataan ke dalam unit makna. Interpreting dilakukan kemudian dengan cara mengembangkan deskripsi tekstural tentang "apakah yang terjadi", di samping itu peneliti melakukan pengembangan deskripsi struktural tentang "bagaimanakah fenomena dialami", dan pengembangan esensi. Langkah keenam adalah visualizing, yaitu peneliti menyajikan narasi tentang esensi pengalaman dalam bentuk deskripsi yang dilengkapi dengan diskusi.

\section{HASIL DAN PEMBAHASAN}

Ada tiga hal yang menjadi hasil penelitian ini meliputi: (1) pemahaman guru tentang kekuasaan, (2) motif guru dalam memilih menjadi pejabat di jajaran birokrasi pemerintah, (3) cara guru meraih kekuasaan birokrasi.

1. Pemahaman Guru tentang Kekuasaan.

Banyak subyek menyadari pentingnya kekuasaan dalam pemerintahan daerah. Bagi mereka kekuasaan tidak boleh diminta. Kekuasaan merupakan amanah yang harus diterima dengan sepenuh hati meskipun berat. Amanah yang datang harus diterima karena yang memberi amanah pasti sudah mempertimbangkannya. Sebagaimana diungkapkan oleh subyek SHR yang berstatus sebagai kepala Dinas Dikdas sebagai berikut:

"Sebagaimana ajaran agama saya, tugas adalah amanah dan amanah harus diterima. Ketika tugas itu diserahkan, saya meyakini bahwa yang memberi tugas itu pasti sudah mengukur kapasitas saya dan saya tidak pernah ragu untuk mengerjakan tugas seberat apapun, apalagi promosi itu karena saya dipandang mampu bukan karena saya meminta jabatan, maka kalau saya ada kekurangan dalam bekerja pasti atasan akan memaklumi".

Pandangan beberapa subyek menyebutkan bahwa jabatan tidak boleh dicari, akan tetapi bila jabatan itu datang maka jabatan tersebut tidak boleh ditolak. Bagi dirinya memegang amanah sangat penting dilakukan sambil belajar apabila merasa ada yang kurang. Hal ini sebagaimana dituturkan oleh salah 
satu subyek dengan inisial SLM sebagai salah satu kabid di kantor dinas Dikdas sebagai berikut:

"Jabatan tidak boleh dicari, tapi kalau diberi tanggung jawab jangan dihindari. Ketika tiba masanya saya diberi jabatan, maka saya harus belajar keras, menyesuaikan, agar saya bisa melaksanakan tugas sebaik-baiknya. Sering saya sampaikan kepada para kepala sekolah dan pengawas bahwa ketika anda diberi tugas itu artinya anda dipandang mampu, yang dibuktikan secara formal dengan SK. Semuanya jangan tanggung-tanggung dalam melaksanakan tugas. Kalau kita tidak bisa jangan segan-segan bertanya, kalau ada yang memberi nasihat jangan segan-segan mendengarkannya".

Paparan di atas menunjukkan pandangan guru bahwa kekuasaan adalah amanah yang harus diemban dengan sepenuh hati meskipun berat. Amanah harus siap diterima karena yang memberi amanah pasti sudah mempertimbangkan masak-masak. Jabatan tidak boleh dicari, tetapi apabila jabatan itu datang maka jabatan tersebut tidak boleh ditolak. Amanah sangat penting dijalankan sebaik-baiknya sambil belajar apabila merasa ada yang kurang.

Secara teoritik, kekuasaan yang dipahami guru di atas merupakan tanggungjawab dan tanggungjawab melaksanakannya berarti ikut berpartisipasi dalam pengambilan keputusan di bidang pendidikan. Hal ini sesuai dengan pendapat Lasswell dan Kaplan (Cheppy Haricahyono,1991) bahwa kekuasaan sebagai 'the participation in the making of decisions'.

Kekuasaan guru dalam jabatan di kantor Dinas Dikdas Pemkab Bantul tergolong jenis transformative power sebagaimana teori yang diungkapkan HAR Tilaar (2003). karena kekuasaan jenis ini adalah kekuasaan yang bertu- juan membentuk hubungan subordinasi antar subyek dengan subyek lain, sehingga memunculkan adanya kepatuhan dan kesetiaan. Kekuasaan guru di Pemerintahan kabupaten Bantul membentuk hubungan legitimatif antara guru dengan Bupati.

2. Motif Guru dalam Memilih Menjadi Pejabat di Jajaran Birokrasi Pemerintah.

Banyak subjek menyadari pentingnya guru masuk menjadi bagian sistem kekuasaan dalam pemerintahan daerah. Dalam pandangan mereka, guru penting untuk terlibat dalam membangun dunia pendidikan. Pembangunan pendidikan perlu dipegang oleh orang yang memahaminya yaitu guru, pendidikan jangan semuanya diserahkan kepada orang lain yang tidak memamahinya. Hal ini antara lain diutarakan oleh subyek SHR sebagai berikut:

"Sesuai dengan visi kabupaten Bantul, wajib kiranya Bantul memiliki pendidikan yang maju, yaitu yang mampu melayani semua anak Bantul di semua lapisan masyarakat menjadi cerdas, terampil, bertaqwa, dan berbudaya Indonesia. Untuk mewujudkan hal tersebut kita wajib terlibat di dalamnya. Jangan sampai upaya pembangunan pendidikan diserahkan kepada orang-orang yang tidak faham dunia pendidikan".

Penuturan senada juga bersumber dari subyek WYN sebagai kepala sekolah yang menganggap bahwa pendidikan dan kekuasaan harus saling mendukung. Pembangunan pendidikan yang tidak didukung oleh penguasa akan lama dan sulit untuk dicapai, sebaliknya pembangunan pendidikan yang didukung oleh penguasa relatif dapat berlangsung lebih cepat. Hal ini sebagai diutarakan oleh WYN sebagai berikut:

"Pendidikan dan kekuasaan adalah dua hal yang mendukung. Keduanya perlu saling menopang satu sama 
lain. Pembangunan pendidikan yang tidak didukung oleh penguasa akan lama dan sulit untuk dicapai, sebaliknya pembangunan pendidikan yang didukung oleh penguasa relatif dapat berlangsung lebih cepat"..

Subyek dari guru juga menyebutkan pentingnya guru memiliki kekuasaan untuk ikut mengatur pendidikan. Pejabat pendidikan yang berasal dari guru akan lebih mengerti tentang pendidikan sehingga kebijakan yang dipilih akan lebih efektif menyelesaikan masalah pendidikan. Hal ini sebagaimana dituturkan oleh SPY sebagai berikut:

"Bila ada peluang untuk masuk ke birokrasi, seharusnya salah satu guru dapat menjadi pejabat yang memiliki kekuasaan di birokrasi pemerintah. Kekuasaan birokrasi pemerintah memiliki kewenangan untuk mengatur pendidikan menjadi lebih baik. Pejabat pendidikan yang berasal dari guru akan lebih mengerti tentang pendidikan. Dengan demikian, kebijakan yang dipilih sudah barang tentu akan lebih efektif dapat menyelesaikan masalah pendidikan".

Beberapa subyek mengaku bahwa motif menjadi pejabat bukanlah keinginannya akan tetapi karena diberi amanah yang harus dijalankan dalam rangka untuk ikut berpartisipasi lebih optimal. Hal ini sebagaimana dituturkan oleh beberapa subyek kepala sekolah sebagai berikut:

"Motivasi saya bersedia menjabat adalah bukan keinginan diri saya, tetapi karena saya diberi amanah yang harus saya terima dan siap saya laksanakan. Ketika tugas itu diserahkan kepada saya, maka tidak boleh ditolak. Ini adalah amanah yang harus dijalankan dengan sepenuh hati"..
Subyek lain menambahkan bahwa motivasi menjabat adalah untuk ikut memperbaiki mutu pendidikan secara lebih optimal. Peran sebagai pejabat yang memiliki kekuasaan lebih diyakini sebagai peluang untuk dapat berbuat lebih banyak dalam mengubah dunia pendidikan menjadi lebih bermutu. Hal ini sebagaimana dituturkan oleh subyek sebagai berikut:

"Bagi saya pribadi, menjabat adalah peluang untuk ikut terlibat dalam memperbaiki mutu pendidikan secara lebih optimal. Sudah barang tentu peran sebagai pejabat yang memiliki kekuasaan lebih saya yakini sebagai peluang untuk dapat berbuat lebih banyak dalam mengubah dunia pendidikan menjadi lebih bermutu".

Pendapat tersebut juga didukung oleh subyek yang berasal dari guru. Subyek ini menuturkan bahwa menjadi kepala sekolah, menjadi kepala bidang, apalagi menjadi kepala dinas Dikdas adalah memiliki peluang cukup besar untuk memperbaiki dunia pendidikan. Menurutnya, seharusnya para pejabat dalam meniatkan dirinya untuk menjabat adalah untuk memperbaiki mutu pendidikan secara langsung, bukan hanya mengejar jabatan semata $\mathrm{Hal}$ tersebut diungkapkan lebih lengkap sebagai berikut:

"Sebagai apapun dalam menjabat jabatan di dalam birokrasi pendidikan pemerintahan daerah, apakah itu sebagai kepala sekolah, kepala bidang, apalagi sebagai kepala dinas adalah orang yang memilik posisi strategis. Mereka memiliki peluang cukup besar untuk memperbaiki dunia pendidikan. Untuk itu, seharusnya para pejabat tersebut harus bisa meniatkan dirinya untuk menjabat adalah untuk memperbaiki mutu pendidikan secara langsung, bukan hanya mengejar jabatan semata". 
Paparan di atas tersebut menunjukkan secara jelas bahwa motif menjadi pejabat bukanlah keinginan para guru akan tetapi karena diberi amanah yang harus dijalankan dalam rangka untuk ikut berpartisipasi lebih optimal, maka jabatan tersebut akan diembannya. Motivasi menjabat dari mereka adalah untuk ikut memperbaiki mutu pendidikan secara lebih optimal. Peran sebagai pejabat yang memiliki kekuasaan lebih diyakini sebagai peluang untuk dapat berbuat lebih banyak dalam mengubah dunia pendidikan menjadi lebih bermutu. Pendapat tersebut juga diungkapkan subyek yang berasal dari guru yang menuturkan bahwa memiliki jabatan penting adalah peluang cukup besar untuk memperbaiki dunia pendidikan.

\section{Cara Guru dalam Meraih Kekuasaan} Birokrasi.

Umumnya pengakuan dari beberapa subyek bahwa usaha guru dalam meraih kekuasaan adalah dicapai melalui organisasi guru. Organisasi guru yang dimaksud adalah PGRI (Persatuan Guru Republik Indonesia). Sebagian subyek mengakui bahwa PGRI memiliki posisi strategis sebagai kendaraan politik menuju kekuasaan. Namun demikian, PGRI menurutnya cenderung dikooptasi oleh penguasa yang bukan dari guru. Hal ini sebagaimana dituturkan oleh subyek sebagai berikut:

"PGRI memiliki posisi strategis dalam menjembatani kepentingan guru dan pemerintah. Namun saya sangat prihatin atas kenyataan yang terjadi, justru PGRI dikooptasi oleh pemerintah melalui usaha-usaha yang dilakukan pemerintah dalam rangka menguasai guru. Sekilas saya melihat pemerintah telah melakukan dua cara untuk menguasai guru, yaitu melalui penguasaan organisasi guru. Misalnya bapak bisa melihat bagaimana PGRI dikuasai oleh orangorang yang berasal dari birokrat".
Menurut penuturan subyek guru SRT di atas diakui oleh SHR selaku Kepala Dinas Dikdas Pemerintahan Kabupaten Bantul yang sekaligus juga merangkap sebagai ketua PGRI kabupaten Bantul. Hal ini diakui oleh yang bersangkutan sebagaimana dituturkan kepada peneliti sebagai berikut.

"Saya Shr, yang memiliki motto hidup selamat dunia akhirat. Karena itu saya harus sehat lahir, jasmani, dan rohani. Dengan mengemban tugas berat selain menjadi kepala Dinas Pendidikan Dasar, saat ini saya juga sebagai ketua PGRI Kabupaten Bantul. Pengalaman jadi pengurus di PGRI sudah lama. Mulai dari menjadi seksi organisasi, kemudian sekretaris bidang hingga wakil ketua, dan sekarang sebagai ketua PGRI Bantul hingga dua periode. Adapun kali ini adalah periode yang terakhir, sampai dengan tahun 2014".

Proses pengangkatan jabatan sebagai Kepala Dinas Dikdas sekaligus juga sebagai ketua PGRI Kabupaten Bantul diakui SHR melalui proses yang amat cepat. Karirnya di birokrasi pemerintah dari seorang ketua PGRI ini dimulai dari kepala cabang (sekarang UPT), empat tahun kemudian naik menjadi kepala subdin Pendidikan Luar Sekolah, 20 bulan berikutnya naik menjadi sekretaris dinas, dan 2 minggu selanjutnya dinaikkan lagi menjadi kepala dinas. Hal ini merupakan karir birokrasi yang amat cepat dari seorang ketua PGRI sebagaimana dituturkan oleh yang bersangkutan sebagai berikut.

"Alhamdulillah pada tahun 2002 saya mendapat tugas sebagai kepala cabang Dinas Pendidikan di kecamatan Kasihan sampai tahun 2006. Kemudian pada tahun 2006 tersebut saya ditugaskan oleh bupati sebagai Kepala subdin pendidikan luar sekolah Dinas Pendidikan. Baru 20 bulan menjadi Kasubdin, kemudian 
saya ditugaskan sebagai sekretaris Dinas Pendidikan Dasar, yaitu pada minggu ketiga bulan Desember 2008. Baru bekerja 2 minggu menjadi sekretaris Dinas, pada tanggal 5 Januari 2009 saya dilantik oleh Bupati Bantul sebagai kepala Dinas Pendidikan Dasar".

Ada enam dari tujuh belas pengurus PGRI kabupaten Bantul yang ditempatkan sebagai pejabat di dalam birokrasi pemkab Bantul. Hal ini berarti juga ada enam pejabat birokrasi pemkab Bantul yang dimasukkan menjadi bagian dari tujuh belas pengurus PGRI kabupaten Bantul. Pengurus PGRI yang menjadi pejabat di birokrasi pemerintah adalah ketua, wakil ketua, wakil sekretaris, bidang ketenagaan dan kesejahteraan, bidang hubungan kerjasama, bidang advokasi dan perlindungan hukum. Hal itu sebagaimana dituturkan oleh sekretaris PGRI Kabupaten Bantul sebagai berikut.

"Sebagian orang kita dapat menduduki jabatan penting di dalam birokrasi pemerintah kabupaten Bantul. Ada enam orang pengurus yang berhasil masuk ke sana. Tiga orang pengurus harian dan tiga orang pengurus bidang di PGRI juga sebagai pejabat penting di pemerintahan".

Paparan di menunjukkan potret yang jelas bahwa sarana para guru untuk dapat sampai pada posisi jabatan tinggi di kantor dinas pendidikan adalah melalui wadah yang disebut PGRI. Sebagai organisasi profesi, PGRI merupakan wadah yang terbesar bagi para guru untuk mengembangkan bakat dan potensinya. Sebenarnya ada banyak organisasi selain PGRI, seperti Asosiasi Guru Indonesia (AGI), Persatuan Guru Swasta Indonesia (PGSI), dan lain-lain. Namun dari banyak organisasi rofesi guru, PGRI lah yang paling populer dan memiliki anggota paling banyak.

\section{SIMPULAN}

Pertama, bahwa pemahaman guru tentang kekuasaan adalah sebagai amanah dan peluang untuk terlibat secara optimal dalam pembangunan pendidikan menuju pada terwujudnya peningkatan mutu pendidikan. Kekuasaan menjabat dalam jajaran birokrasi pemerintah adalah penting, sebab bila jabatan tersebut dipegang oleh orang-orang yang tidak mengetahui pendidikan akan berakibat fatal. Oleh karena itu, amanah yang telah diberikan oleh pemerintah kepaga guru harus dijalaankan dengan sungguhsungguh sepenuh hati.

Kedua, motif guru dalam memilih menjadi pejabat di jajaran birokrasi pemerintah adalah agar menjadi pelaku langsung dalam pembangunan pendidikan. Menjadi pejabat bagi guru adalah penting dari pada jabatan tersebut dipegang oleh orang yang tidak mengetahui pendidikan. Apabila jabatan dipegang oleh orang yang tidak memahami pendidikan maka akan berakibat fatal.

Ketiga, cara guru dalam meraih kekuasaan birokrasi adalah melalui PGRI. Penguasa sangat berkepentingan terhadap PGRI dalam rangka menguasai ara guru. Dengan demikian PGRI dipakai oleh penguasa daerah sebagai alat untuk kooptasi guru. Dampaknya adalah para pengurus PGRI banyak yang diangkat oleh Bupati dijadikan pejabat di kantor Dinas Pendidikan Dasar dan kantor Dinas Pendidikan Menengah dan Nonformal. Ad enam pengurus PGRI yang merangkap jabatan penting di kantor dinas Pendidikan Pendidikan Dasar dan kantor Dinas Pendidikan Menengah dan Nonformal tersebut.

Berdasarkan kesimpulan penelitian di atas, maka dapat dibuat rekomendasi atau saran-saran kepada banyak pihak, diantaranya adalah: (1) guru perlu mencari cara yang paling efektif agar lebih otonom sehinggs tidak banyak dipengaruhi oleh penguasa politik di daerah; (2) Dengan telah diberlakukannua Undang-Undang 14/2005 tentang guru dan dosen maka menuntut cara guru untuk lebih rofesional, lebih-lebih dengan telah adanya sertifikasi guru. Untuk 
itu bila ada guru yang berkeinginan berkarir di bidang struktural birokrasi maka harus keluar dari berprofesi sebagai guru mengingat jabatan struktural tidak boleh dicampuradukkan dengan jabatan fungsional.

\section{DAFTAR PUSTAKA}

Cheppy Haricahyono. (1991). Ilmu Politik dan Perspektifnya. Yogyakarta: Tiara Wacana.

Cresswell, J. W. (2007). Qualitative inquiry \& research design: choosing among five approaches (second edition). London: Sage publications.

Dirto Hadisusanto dkk. (1995). Pengantar Ilmu Pendidikan. Yogayakarta: FIP IKIP Yogyakarta

HAR Tilaar. (2003). Kekuasaan dan Pendidikan. Magelang: Indonesiatera.

Laksana, S.D. (24 Nopember 2011). Kasihanilah kepala daerah. Kedaulatan Rakyat, Yogakarta, p.4. Ramlan Surbakti. (1992). Memahami Ilmu Politik. Jakarta: Gramedia Widiasarana Indonesia Rubin, J. and
Fausset, R. (2005). Mayor Ttalks Ttough to Push School Takeover. Los Angeles Times, November 21, 2005. p. A1.

Sack, Joetta L. (2002). "Hard bargaining". Education Week Volume 21 Apr 24, 2002;

Spring, Joel. (1993). Conflict of Interests: The Politics of American Education. New York: Longman.

Umar Tirtaraharja dan La Sulo. (1996). Pengantar Pendidikan. Jakarta: Ditjend Pendidikan Tinggi.

Wagman, J. (2003). Power Brokers Play Role in Campaign for School Reform. St. Louis Post-Dispatch, July 20. p. C4.

Wong, Kenneth K. (2006). The Political Dynamics of Mayoral Engagement in Public Education. Harvard Educational Review. Cambridge: Summer 2006. Vol. 76, Iss. 2.

Zen Rachmat Sugito dkk. (2006). Sang Guru: Peta Ringkas Hubungan Guru-Murid di Pelbagai Tradisi. Yogyakarta:Ekspresi Buku LPM UNY 